\title{
Neke odrednice policijskoga postupanja pri prekršaju iz Zakona o šumama i ostalim nedopuštenim radnjama vezanim uz šume
}

\author{
Goran Matijević, Malči Grivec, Željko Zečić
}

\begin{abstract}
Nacrtak - Abstract
Šume $i$ šumska zemljišta specifično su prirodno bogatstvo Republike Hrvatske. Primarna zadaća održivoga gospodarenja šumama pripada privatnim $i$ javnim šumoposjednicima, pri čemu državnim šumama gospodare Hrvatske šume d.o.o i druge ustanove. Inspekcija i nadzor u šumarstou, sukladno Zakonu o državnom inspektoratu, u nadležnosti je šumarske inspekcije, a unutar Hrvatskih šuma ustrojeni su odjeli za reviziju i nadzor. Uz njih neizostavnu ulogu u prevenciji $i$ otkrivanju prekršaja $i$ kaznenih djela vezanih uz šume imaju službenici policije koji tako pridonose interesima Republike Hrvatske u zaštiti šuma. Članak sadrži prijedloge uputa za njihovo postupanje, ali može biti od koristi ostalim inspekcijama $i$ službama kako bi prepoznali nezakonitosti u situacijama nadzora sječe, prijevoza i prometa šumskim proizvodima (dronim i nedronim), kada se osobe zateknu u kršenju zakonskih propisa iz toga područja te ostalih kaznenih djela i prekršaja koji se pojavljuju u tim slučajevima. Nadalje, daje se uputa kako kriminalističkim istraživanjem pravilno utvrditi činjenično stanje te kako provesti postupak podnošenja odgovarajućih dopisa s prilozima, odnosno dokazima nadležnoj inspekciji, prekršajnim sudovima ili državnomu odvjetništou. Istodobno nedopuštene radnje opisane u članku u nekoliko slučajeva mogu imati obilježja kaznenih djela krađe, krivotvorenja isprava, ovjeravanja neistinitoga sadržaja, zlouporabe položaja i ovlasti. Rad obuhvaća i postupak kriminalističkoga istraživanja, izvida i podnošenja odgovarajućega izvješća ili kaznene prijave nadležnomu Državnomu odvjetništou, koje je odgovorno za progon počinitelja kaznenih djela, ali je sukladno ovlastima legitimno.
\end{abstract}

Ključne riječi: pravni propisi, šumski proizvodi, prekršaj, kazneno djelo, policijska inspekcija

\section{Uvod - Introduction}

U radu se analiziraju zakonske i podzakonske odredbe* te nekoliko situacija koje izazivaju nedoumicu i nejasnoće u primjeni Prekršajnoga zakona (Narodne novine, 107/07, 39/13, 157/13, 110/15, 70/17, 118/18; u nastavku PZ/07'), Zakona o šumama (Narodne novine, 68/18, 115/18, 98/19, 32/20, 145/20; u nastavku ZŠ/182) i Kaznenoga zakona (Narodne novine, 125/11, 144/12, 56/15, 61/15, 101/17, 118/18,

U radu autori uz zakonske odrednice iznose svoja osobna stajališta.

Prekršajni zakon. NN 107/07, 39/13, 157/13, 110/15, 70/17, 118/18.

2 Zakon o šumama. NN 68/18, 115/18, 98/19, 32/20, 145/20.
126/19; u nastavku $\mathrm{KZ} / 11^{3}$ ), odnosno one situacije koje dovode do različitih pristupa i poimanja te obveze provođenja pojedinih radnji (svatko je dužan prijaviti kazneno djelo za koje se postupak pokreće po službenoj dužnosti), kako u policijskoj službi tako i kod šumarske inspekcije, pa se postavlja pitanje načina pravilnoga postupanja u tim situacijama, odnosno pravilne uporabe zakonskih i podzakonskih rješenja koja propisuju ta postupanja. Nakon nekoliko postupanja, koja su potvrđena $\mathrm{u}$ inspekciji, državnom odvjetništvu i nadležnim sudovima, predlaže se radi učinkovitijega i ujednačenoga postupanja njihova primjena. Situacije će se razmotriti

Kazneni zakon. NN 125/11, 144/12, 56/15, 61/15, 101/17, $118 / 18,126 / 19$. 
tako da se prvo iznese zakonska regulativa, a zatim ponudi prijedlog uputa za postupanje.

\section{Zakonski preduvjeti za postupanje - Legal preconditions for action}

Člankom 37. ZŠ/18 propisano je da se drvni šumski proizvodi i drvo posječeno izvan šume i šumskoga zemljišta mogu transportirati (zakonski pojam obuhvaća otpremu, prijevoz i pohranu) samo ako su propisano obilježeni i ako je za njih izdan propisani teretni list (popratnica). Člankom 36. $Z S ̌ / 18$ propisano je da je u šumi i na šumskom zemljištu dopušteno sjeći samo doznačena stabla, a da doznaku stabala u šumama i na šumskom zemljištu obavlja izvoditelj šumarskih radova koji posjeduje odgovarajuću licenciju Komore (Hrvatska komora inženjera šumarstva i drvne tehnologije). U skladu s potrebom stupnjevanja pojedine odgovornosti i vrste kažnjivih radnji zakonodavac je u ZŠ/18 propisao prekršajne odredbe u dijelu XI. Zakona (novčane kazne), i to za velike, srednje i male šumoposjednike, ustanove, javne ustanove i pravne osobe šumoposjednike te pravne osobe i fizičke osobe koje nisu šumoposjednici. Ovdje je vidljiva značajna novost u odnosu na prijašnja zakonska rješenja iz Zakona o šumama, koji je kao i u drugim zakonima iz prekršajne domene propisivao i stupnjevao odgovornost pravne, odgovorne i fizičke osobe. Sada se odgovornost propisuje i dijeli na velike, srednje i male šumoposjednike, te na šumoposjednike kao fizičke i pravne osobe i osobe koje to nisu. To je s gledišta načela pokretanja i vođenja prekršajnoga postupka složenija zadaća za inspekciju ili tijela koja pokreću postupak, uključujući i policiju, jer moraju podrobno utvrditi svojstvo počinitelja i svojstvo oštećenika, koje onda usmjerava u kojem smjeru trebaju ići izvidi i radnje i što treba poduzeti. Tako, na primjer, sječa stabla i krađa šumskih proizvoda u šumi u vlasništvu Republike Hrvatske, bez obzira na vrijednost, progoni se kao kazneno djelo po službenoj dužnosti, a u šumi privatnih vlasnika kazneni ili prekršajni postupak ovisi o imovinskom cenzusu ili stavljanju prijedloga za progon počinitelja.

Ako se krađa pak, na primjer, počini u šumi koja nije vlasništvo Republike Hrvatske, za kazneno djelo krađa male vrijednosti ${ }^{4}$ protiv poznatoga počinitelja sječe i transporta bez doznake i teretnoga lista bit će, uz dostavljanje podataka oštećenomu za pokretanje privatne tužbe (ako je vrijednost ukrade-

\footnotetext{
4 Člankom 87. stavkom 3. Kaznenoga zakona Republike Hrvatske propisano je da se u slučaju vrijednosti do 1000 kuna radi o vrijednosti, stvari i prava koje je mala.
}

ne stvari mala), pokrenut prekršajni postupak zbog prekršaja iz Zakona o šumama.

Uz složenije određivanje svojstva oštećenoga i počinitelja, ovo je u Zakonu o šumama istodobno i kvalitetno rješenje koje obuhvaća sve vlasnike i strukture gospodarenja šumama te fizičke i pravne osobe koje posluju drvnim sortimentima i na određen način vrstom i visinom kazne delegira pojedinu odgovornost.

Prekršaji iz Zakona o šumama, koji se najčešće mogu pojaviti u inspekcijsko-policijskoj praksi, jesu ovi:

U vezi s kršenjem odredaba članka 36. stavka 1. ZŠ/18 (u šumi se mogu sjeći samo doznačena stabla) člankom 82. stavkom 1. točkom 1 . ZŠ/18 propisano je da će se novčanom kaznom od 30 000,00 do 70 000,00 kuna kazniti za prekršaj javni šumoposjednik, ustanova ili pravna osoba koja izvrši ili dopusti sječu nedoznačenih stabala. Isto tako, člankom 82. stavkom 1. točkom 3. ZŠ/18 propisano je da će javni šumoposjednik, ustanova ili pravna osoba biti kažnjena novčanom kaznom od 30 000,00 do 70 000,00 kuna ako šumske proizvode i drvo izvan šume i šumskoga zemljišta transportira neobilježeno i ako za njih nema izdan propisani teretni list (članak 37. stavci 1, 2, 4, 7).

Novčanim kaznama u iznosu od 10 000,00 do 30 000,00 kuna člankom 85. ZŠ/18 propisano je da će za počinjeni prekršaj iz članaka 36 . i 37 . ZŠ/18 biti kažnjen veliki $i$ srednji šumoposjednik ${ }^{5}$ (mogu, ali i ne moraju biti pravne osobe) ako izvrši ili dopusti sječu nedoznačenih stabala (članak 36. stavak 1), izvrši ili

\footnotetext{
U smislu Zakona o šumama (članak 14. ZŠ/18) šumoposjednici su:

a) javni šumoposjednik je pravna osoba koja je ovim Zakonom ovlaštena za gospodarenje šumom i/ili šumskim zemljištem u vlasništvu Republike Hrvatske

b) pravna osoba sa statusom javne ustanove čiji je osnivač Republika Hrvatska i njezine znanstveno-nastavne sastavnice, koje svoju znanstveno-nastavnu djelatnost i znanstvenoistraživački rad obavljaju iz područja šumarstva (u daljnjem tekstu: Ustanova) c) pravna osoba čiji je osnivač i vlasnik jedinica lokalne samouprave, a kojoj je odlukom Vlade iz članka 16. stavka 3. povjereno gospodarenje (u daljnjem tekstu: Pravna osoba)

d) privatni šumoposjednik je pravna ili fizička osoba koja je vlasnik šume i/ili šumskoga zemljišta te posjednik na temelju pravnoga posla.

(3) Prema površini šume i šumskoga zemljišta privatni šumoposjednik može biti:

a) mali šumoposjednik s površinom šuma i/ili šumskoga zemljišta do 20 ha

b) srednji šumoposjednik s površinom šuma i/ili šumskoga zemljišta većom od 20, a manjom od 300 ha

c) veliki šumoposjednik s površinom šuma i/ili šumskoga zemljišta većom od 300 ha.
} 
dopusti izvršenje doznake stabala $u$ šumi protivno odredbama članka 36. stavaka 2, 5, 6. Zakona o šumama i ako šumske proizvode i drvo izvan šume i šumskoga zemljišta transportira neobilježeno i ako za njih nema izdan propisani teretni list (članak 37. stavci $1,2,5,7)$.

Odgovornost malih šumoposjednika (koji su u većini slučajeva fizičke osobe) za počinjenje prekršaja iz članaka 36. i 37. ZŠ/18 propisana je i kažnjiva člankom 88 . ZŠ/18 koji propisuje da je u šumama malih šumoposjednika također kažnjivo vršiti ili dopustiti sječu nedoznačenih stabala (članak 36 . stavak 1), vršiti ili dopustiti izvršenje doznake stabala u šumi protivno odredbama članka 36. stavaka 2, 5, 6. Zakona o šumama i šumske proizvode i drvo izvan šume i šumskoga zemljišta transportirati neobilježeno i ako za njih nije izdan propisani teretni list (članak 37. stavci 1, 2, 7).

Opisani prekršaji, promatrano iz dugogodišnje prakse, rjeđe se čine, ali su još uvijek prisutni, posebice kod malih šumoposjednika ili novoregistriranih pravnih osoba šumoposjednika koji djelomično ne poznaju propise ili olako pristaju na njihovo kršenje. Uglavnom su u proteklom razdoblju utvrđivani djelovanjem i radom šumarskih inspektora, no ne treba zanemariti ni ulogu policije koja, primjerice, pri transportu neobilježena drva bez teretnoga lista, osim radnji u dogovoru s inspektorom vezanih uz pokretanje postupka za taj prekršaj, treba provesti i utvrđivanje činjeničnoga stanja s obzirom na mjesto sječe i jesu li bili ispunjeni uvjeti za doznaku.

Češći su prekršaji iz Zakona o šumama s kojima se policija susreće prekršaji pravnih i fizičkih osoba koji nisu šumoposjednici.

Tako će pravna osoba koja nije šumoposjednik, temeljem članka 91. ZŠ/18, biti kažnjena novčanim kaznama od 30 000,00 do 70 000,00 kuna ako (navedeni su najčešći prekršaji iz Zakona):

$\Rightarrow$ izvrši sječu nedoznačenih stabala (članak 36 . stavci 1. i 2. ZŠ/18, bez obzira u čijem vlasništvu, u šumi i na šumskom zemljištu)

$\Rightarrow$ šumske proizvode i drvo izvan šume i šumskoga zemljišta transportira neobilježeno i ako za njih nema izdan propisani teretni list (članak 37. stavak 1, 2), čime se bez oznake i teretnoga lista zabranjuje prijevoz šumskih proizvoda iz šume i drva izvan šume, odnosno svaki drvni sortiment u transportu mora biti upisan u odgovarajući teretni list

$\Rightarrow$ šumama kojima gospodari ustanova i privatni šumoposjednik obavlja obilježbu i izdavanje teretnih listova, a ne posjeduje odgovarajuću licenciju Komore (članak 37. stavak 5)
$\Rightarrow$ ne poštuje uvjete, način doznake stabala, sadržaj teretnoga lista (manjkavosti ili nelogičnosti u teretnom listu mogu upućivati na moguća kršenja zakona, što policijski službenici mogu uočiti prilikom nadzora prometa), obilježbu šumskih proizvoda (također službenici policije prilikom nadzora prometa trebaju provjeriti), njihovu otpremu, prijevoz (ukupna masa, odgovarajući teretni list, odgovarajuće vozilo) i pohranu, kao i vrijeme sječe i šumski red koje ministar propisuje pravilnikom (članak 37. stavak 7).

Fizičke osobe koje nisu šumoposjednici, a dolaze u kontakt s drvetom i šumskim proizvodima sukladno članku 92. ZŠ/18 bit će kažnjene novčanom kaznom u iznosu od 10 000,00 do 20 000,00 kuna ako:

$\Rightarrow$ izvrše sječu nedoznačenih stabala (članak 36 . stavak 1)

$\Rightarrow$ šumske proizvode i drvo izvan šume i šumskoga zemljišta transportiraju neobilježeno i ako za njih nemaju izdan propisani teretni list (članak 37. stavci 1,2)

$\Rightarrow$ ne poštuju odredbe vezane uz prijevoz i pohranu, kao vrijeme sječe i šumski red koje ministar propisuje pravilnikom (članak 37. stavak 7)

$\Rightarrow$ sijeku grane, ako to nije predviđeno šumskogospodarskim planovima, obavljaju pašarenje, brst i žirenje, skupljaju i odnose šušanj, mahovine, šumske plodove i druge šumske proizvode, odnose humus, treset, i dr. (članak 38. stavak 2)

$\Rightarrow \mathrm{u}$ šumi ili na šumskom zemljištu te na zemljištu 50 metara od ruba šume lože otvorenu vatru i pale drveni ugljen (članak 45. stavak 1)

$\Rightarrow$ u šumi odlažu otpad (članak 45. stavak 3)

$\Rightarrow$ motornim se vozilom voze izvan šumskih prometnica bez dozvole šumoposjednika (članak 47. stavak 5), što je čest slučaj ljeti kada se dvokotačni i četverokotačni motocikli voze šumama

$\Rightarrow \mathrm{u}$ šumama $\mathrm{u}$ vlasništvu Republike Hrvatske obavljaju radove pridobivanja drva iz šume isključivo za vlastite potrebe (ogrjevno drvo u količini do $30 \mathrm{~m}^{3}$ godišnje - samoizrada) a da nisu osposobljene i/ili bez dozvole te bez nadzora pravne osobe koja gospodari tim šumama (članak 50. stavak 3)

$\Rightarrow$ neovlašteno zauzmu šumu i šumsko zemljište (članak 57) (ograđivanjem za primjerice ispašu, smještaj motornih vozila, odlaganje raznih predmeta itd.).

U dijelu X. ZŠ/18 propisano je da upravni nadzor nad provedbom Zakona o šumama i propisa donesenih na temelju njega, u dijelu povjerenih javnih 
ovlasti, obavlja Ministarstvo. Inspekcijski nadzor nad provedbom Zakona o šumama i propisa donesenih na temelju njega obavljaju državni šumarski inspektori. ${ }^{6}$ Stručni nadzor kvalitete obavljenih radova ovlaštenih inženjera na gospodarenju šumama i šumskim zemljištima obavlja Komora kao javnu ovlast na zahtjev Ministarstva ili drugih osoba koje imaju pravni interes. Iznimno, inspekcijski nadzor nad provedbom Zakona o šumama i propisa donesenih na temelju njega u području trgovine obavlja se prema posebnim propisima (Zakon o trgovini i Zakon o zabrani i sprječavanju obavljanja neregistrirane djelatnosti). Nadzor nad provedbom mjera zaštite od požara u šumama i na šumskom zemljištu obavljaju i inspektori zaštite od požara ministarstva nadležnoga za unutarnje poslove. Nadzor nad provedbom mjera iz programa gospodarenja gospodarskom jedinicom s planom upravljanja područjem ekološke mreže i programa zaštite, njege i obnove šuma koordinirano obavljaju šumarski inspektori i inspektori zaštite prirode. U slučaju izdvajanja poljoprivrednoga zemljišta radi poljoprivredne proizvodnje nadzor nad provedbom mjera iz članka 52. stavka 6. Zakona o šumama obavljaju poljoprivredni inspektori.

Unatoč velikomu broju određenih nadležnih osoba ili inspektora za nadzor odredaba Zakona o šumama, policija, koja je državno tijelo koje je 24 sata prisutno na terenu, ima obvezu suradnje kao i kod drugih zakona u kojima nije neposredni ovlaštenik za nadzor, i to temeljem Zakona o policiji ${ }^{7}$ i Zakona o sustavu državne uprave, jer iz tih zakona izlazi obveza policije da tim tijelima pruži pomoć i dostavi obavijesti o kojima vodi službene očevidnike (Pohraški i Tršinski 2009).

Konkretno postupanje policije pri sumnji u počinjene prekršaje iz Zakona o šumama može ići u tri smjera. U prvom, po saznanju za prekršaj (najčešće kod osoba u prekršaju, primjerice $\mathrm{u}$ transportu bez teretnoga lista) policija odmah (najčešće telefonom) izvješćuje nadležnoga šumarskoga inspektora, ${ }^{8}$ koji izlazi na teren te sukladno svojim ovlastima preuzima radnje inspekcijskoga nadzora od policije, koja mu po potrebi pruža pomoć na mjestu prekršaja.

\footnotetext{
Člankom 14. Zakona o Državnom inspektoratu (NN 115/18) propisan je djelokrug rada šumarske inspekcije.

Zakon o policiji. NN34/11, 130/12, 89/14, 151/14, 33/15,121/16, 66/19.

8 Popis kontakata Državnoga inspektorata, područnih inspektora i njihovi kontakti dostupni su na: https://dirh.gov.hr/ kontakti/podrucni-uredi/331
}

Ako nije moguć izlazak inspektora na mjesto događaja i preuzimanje postupanja, na mjestima koja se mogu osigurati do njegova dolaska potrebno ih je osigurati, posebice kada se radi o složenijim kršenjima Zakona o šumama koja traže znanja koja posjeduje šumarski inspektor, a sve kako bi se osigurali dokazi za uspješno vođenje prekršajnoga postupka.

U trećem slučaju, kada nije moguć izlazak inspektora na mjesto događaja, policija će poduzeti samostalno radnje, ali se preporučuje također izvijestiti inspektora telefonski o njem i tako koordinirati postupanje da se ne bi propustila bitna radnja. To se smatra vođenjem prekršajnoga postupka po službenoj dužnosti, jer policija tada nakon poduzetih radnji podnosi obavijest o počinjenom prekršaju tijelu koje vodi prekršajni postupak, a to je u ovom slučaju šumarski inspektor. Takve obavijesti i prijave policije o počinjenom prekršaju koje, iako u pravilu imaju sadržaj optužnoga prijedloga, to formalno nisu zato što policija nije ovlaštena za nadzor nad provođenjem zakona (u ovom slučaju Zakona o šumama), u kojem je propisan prekršaj koji je uočen tijekom obavljanja redovitih policijskih poslova i policija ne može optužne prijedloge za prekršaje iz Zakona o šumama dostavljati izravno prekršajnomu sudu (Gospočić 2018).

Policija pri postupanju i u slučaju sumnje na prekršaj iz Zakona o šumama, kao i kod svih ostalih prekršaja kada postupa u okviru svoje nadležnosti, postupa sukladno odredbama članka 158. PZ/07 Republike Hrvatske, odnosno dužna je poduzeti potrebne izvide i mjere da se:

1. utvrdi je li počinjen prekršaj i tko je počinitelj

2. počinitelj ili sudionik ne sakrije ili pobjegne

3. otkriju i osiguraju tragovi prekršaja i predmeti koji mogu poslužiti pri utvrđivanju činjenica

4. prikupe sve obavijesti koje bi mogle biti od koristi za uspješno vođenje prekršajnoga postupka.

Policija radi ispunjenja tih zadaća može:

1. tražiti potrebne obavijesti od građana

2. obaviti potreban pregled prijevoznih sredstava, osoba i prtljage

3. u najkraćem potrebnom vremenu, a najdulje šest sati, nadzirati i ograničiti kretanje određenih osoba na određenom prostoru

4. poduzeti druge mjere za otkrivanje osoba i stvari (promatranje, pratnja, blokada, racija, zasjeda, klopka, i dr.) 
5. poduzeti potrebne mjere $\mathrm{u}$ vezi s utvrđivanjem istovjetnosti osoba i predmeta

6. u nazočnosti odgovorne osobe obaviti pregled određenih objekata i prostorija državnih tijela, pravnih osoba te drugih poslovnih prostora $\mathrm{i}$ ostvariti uvid u njihovu dokumentaciju i podatke

7. poduzeti i druge potrebne mjere i radnje.

O činjenicama i okolnostima koje su utvrđene prilikom poduzimanja opisanih mjera, a od interesa su za prekršajni postupak, sastavit će se službena zabilješka, koja se uz obavijest o počinjenom prekršaju dostavlja tijelu koje vodi prekršajni postupak (u ovom slučaju šumarska inspekcija).

Zapisnik o ispitivanju svjedoka ili osumnjičenika u slučaju prekršaja iz Zakona o šumama policija ne bi trebala sastavljati jer Prekršajni zakon, člankom 158. stavkom 1. točkama 6. i 7, propisuje da se oni sastavljaju samo kada državna tijela postupaju po zakonima koji su im u nadležnosti. Temeljem poduzetoga i utvrđenoga obavijest o počinjenom prekršaju protiv počinitelja koja će biti dostavljena nadležnoj šumarskoj inspekciji mora sadržavati podatke za uspješno vođenje postupka, odnosno podnošenja optužnoga prijedloga šumarske inspekcije nadležnomu prekršajnomu sudu. Uz propisane podatke $u$ obavijesti vrlo je važno za postupak u službenoj zabilješki opisati i priložiti priloge i dokaze kako bi se postupak uspješno priveo kraju osuđujućom presudom, odnosno vodio sa što manje nedoumica. Tako se kao dokazi mogu koristiti fotografije, mjerenje uz fiksiranje i dosljedno i točno opisivanje oduzetih predmeta, potvrde o privremenom oduzimanju predmeta i oduzeti predmeti (teretni list, zapis tahografa, drvni obujam proizvoda i sl.).

Iz zakonskih rješenja Zakona o šumama razvidna je široka lepeza aktivnosti kojima zakonodavac usmjerava građane na propisano ponašanje i propisuje nedopuštena i nepropisana ponašanja (sječa, prijevoz, otprema, pohrana, prodaja, kupnja, zaštita šuma itd.), a sve kako bi osigurao gospodarenje šumama na načelima gospodarske održivosti. No, pri postupanju policije uz Zakon o šumama svakako valja voditi računa, o čem će biti riječi u daljnjem tekstu, da počinitelji često mogu, a i čine pri manipulaciji drvnim proizvodima i ostala kaznena djela i prekršaje, a ponajprije kazneno djelo iz članka 228. KZ/11 (krađa), krivotvorenja isprava iz članka 278, ovjeravanje neistinitoga sadržaja iz članka 281, zlouporabe položaja i ovlasti iz članka 291. te prekršaj iz članka 4. Zakona o trgovini Republike Hrvatske (neregistrirana djelatnost $\mathrm{u}$ trgovini).

\subsection{Pravilnik o doznaci stabala, obilježbi šumskih proizvoda, teretnom listu (popratnici) i šumskom redu - Regulations on tree marking, labeling of forest products, waybill contents (letter of transmittal) and forest rules and regulations}

Pravilnik o doznaci stabala, obilježbi šumskih proizvoda, teretnom listu (popratnici) i šumskom redu ${ }^{9}$ donio je ministar poljoprivrede Republike Hrvatske i trenutačno je važeći onaj iz 2019. godine. Njime se propisuju uvjeti i način doznake stabala, sadržaj teretnoga lista (popratnice), obilježbe šumskih proizvoda, njihova otprema, prijevoz i pohrana te vrijeme sječe i šumski red.

Pod doznakom se razumijeva odabiranje, obilježavanje i mjerenje stabala za sječu te obračun drvnoga sječivoga obujma. Doznakom se obuhvaćaju sva stabla predviđena za sječu prsnoga promjera $10 \mathrm{~cm}$ i većega od $10 \mathrm{~cm}^{10}$. Doznaka se stabala obavlja prema šumskouzgojnim načelima, smjernicama i načinu gospodarenja propisanim šumskogospodarskim planovima, a u šumama za koje nije izrađen šumskogospodarski plan u skladu sa šumskouzgojnim načelima i načelom održivoga gospodarenja šumama. Doznačena stabla mjere se i obilježavaju u prsnoj visini (približno 1,30 m od tla), na nagnutim terenima s gornje strane, na mrtvoj kori oznakama vidljivim sa svih strana stabla (boja, zates i dr.) i otiskom žiga doznačnoga čekića (promjer $35 \mathrm{~mm}$ ) na zatesu žilišta (prilikom izvida kaznenih djela ili prekršaja to je mjesto na kojem se fiksiraju tragovi, odnosno utvrđuje je li srušeno stablo bilo doznačeno ili nije), a otisak mora biti vidljiv nakon sječe. Doznaku stabala obavlja osoba sa završenim dodiplomskim, preddiplomskim i diplomskim sveučilišnim studijem šumarstva, a iznimno $u$ zaštićenim šumama i u urbanim šumama doznaku može obavljati osoba sa završenim preddiplomskim i diplomskim sveučilišnim studijem urbanoga šumarstva, zaštite prirode i okoliša.

Obilježavanje drvnih sortimenata obavlja se obvezno prije njihova stavljanja u transport, i to režijskim čekićem koji ima oblik istostraničnoga trokuta sa zaobljenim vrhovima i dužinom stranice od 35 $\mathrm{mm}$, čiji se otisak otisne na čelo sortimenta. Otisak mora biti vidljiv. ${ }^{11}$ Drvni sortimenti obloga teh-

Pravilnik o doznaci stabala, obilježbi šumskih proizvoda, teretnom listu (popratnici) i šumskom redu. NN 71/2019.

10 Čl 2. Pravilnika o doznaci stabala, obilježbi šumskih proizvoda, teretnom listu (popratnici) i šumskom redu. NN 71/2019.

11 Čl. 7. i 18. Pravilnika o doznaci stabala, obilježbi šumskih proizvoda, teretnom listu (popratnici) i šumskom redu. NN $71 / 2019$. 
ničkoga drva (trupci, tanka oblovina i obla građa) srednjega promjera ispod $25 \mathrm{~cm}$ obilježavaju se na jednom čelu, a srednjega promjera $25 \mathrm{~cm}$ i većega na oba čela. Višemetarsko prostorno drvo promjera 7 $\mathrm{cm}$ i većega obilježava se u složaju na $50 \%$ komada s jedne strane složaja. Jednometarsko prostorno drvo promjera $7 \mathrm{~cm}$ i većega obilježava se u složaju na 50 $\%$ cjepanica odnosno oblica s jedne strane složaja ili $30 \%$ sa svake strane složaja. Prostorno drvo dimenzija kraćih od $1 \mathrm{~m}$, koje zbog dimenzije nije moguće složiti u složajeve, obilježava se na jednom čelu na $20 \%$ cjepanica odnosno oblica. ${ }^{12}$ Posječeni i izrađeni drvni sortimenti obloga tehničkoga drva prije transporta obilježavaju se identifikacijskom pločicom. Iznimno u šumama malih i srednjih šumoposjednika te na površinama izvan šuma tehničko se drvo može, do izdavanja identifikacijske pločice, obilježavati rednim brojem.

Nejasni, nevidljivi ili nedovoljno otisnuti znakovi režijskoga čekića, nedostatak pločica kod tehničkoga drva prilikom nadzora prometa policijskih službenika mogu upućivati na sumnju u manipulaciju pa treba provesti sve radnje kako bi se otklonila sumnja, odnosno dokazao prekršaj ili kazneno djelo.

Grane i dijelovi grana, drvna sječka te ostali šumski proizvodi koji se ne mogu obilježiti režijskim čekićem pri stavljanju u transport ne moraju biti obilježeni.

Teretni list (popratnica) za drvne šumske proizvode i drvo posječeno izvan šume i šumskoga zemljišta pisana je jedinstveno numerirana isprava koja se izdaje prije transporta svih drvnih i nedrvnih šumskih proizvoda $i$ drveta posječena izvan šume i šumskoga zemljišta. ${ }^{13}$ Teretni list (popratnica) ima vremenski ograničeno važenje koje iznosi 24 sata. Za ovjeru teretnoga lista (popratnice) koristi se jedan od žigova ili faksimila režijskoga čekića licenciranoga izvođača koji je obavio obilježavanje drvnih sortimenata, te tako otisak žiga na drvnom sortimentu u prijevoznom sredstvu i na popratnici moraju biti jednaki. Ako nisu, pojavljuje se sumnja u manipulaciju, a to može upućivati i na sumnju u počinjenje kaznenoga djela krivotvorenja službene isprave. O preuzetim obrascima teretnih listova vodi se očevidnik preuzetih obrazaca teretnih listova te je propisana godišnja inventura.

Teretni list (popratnica) izdaje se na obrascima ili kao računalni ispis za:

12 Čl. 19. Pravilnika o doznaci stabala, obilježbi šumskih proizvoda, teretnom listu (popratnici) i šumskom redu. NN 71/2019.

13 Čl.23-29. Pravilnika o doznaci stabala, obilježbi šumskih proizvoda, teretnom listu (popratnici) i šumskom redu. NN $71 / 2019$.
$\Rightarrow$ oblo drvo na obrascu TL-1

$\Rightarrow$ prostorno drvo i drvnu sječku na obrascu TL-2

$\Rightarrow$ nedrvne šumske proizvode na obrascu TL-NŠP.

Teretni se list ispunjava u četiri primjerka, od kojih jedan primjerak ostaje u bloku, jedan primjerak pripada šumoposjedniku/vlasniku i/ili posjedniku površine koja nije šuma, jedan primjerak prijevozni$\mathrm{ku}$, a jedan primjerak treba biti predan kupcu, čime se osigurava sljedivost praćenja šumskih proizvoda te omogućuje nadzor inspekciji ili policiji pri sumnji na kaznena djela. Teretni listovi mogu biti dokazi u postupcima kad se sumnja na razne prekršaje ili kaznena djela. Kad je riječ o Zakonu o šumama, njima se provjerava niz obveznih postupanja, primjerice o limitu od 30 metara kubnih samoizrade godišnje, zatim provjeravaju se prekršaji iz Zakona o trgovini (neregistrirana djelatnost) za prijevoznike i prodavatelje itd.

Iz prenesenih zakonskih, podzakonskih akata i uredbi koje propisuju ili se dotiču ove tematike razvidno je da inspekcijskim tijelima, odnosno $u$ ovom slučaju policiji zakonski i podzakonski akti jasno i decidirano propisuju što sve šumoposjednici, izvoditelji radova, prijevoznici, kupci itd. moraju poduzeti prije sječe i puštanja u promet drvnih proizvoda.

\section{Postupanje policije u pojedinim slučajevima - Police action in individual cases}

\subsection{Vozila za prijevoz drvnih proizvoda $i$ uvjeti za sudjelovanje u prometu - Vehicles for transport of timber products and conditions for participation in traffic}

Najčešća vozila koja se nalaze na našim prometnicama, a kojima se prevoze šumski proizvodi, za to su prilagođena teretna i pridodana im priključna vozila s prilagođenim prostorom za smještaj trupaca ili cijepanoga i obloga jednometarskoga ogrjevnoga drva i pri tom ugrađenom hidrauličnom dizalicom sa zglobnim hvatalom, koja se, ovisno o namjeni vozila, postavlja ispred ili iza tovarnoga prostora i koristi za manipulaciju drvnim proizvodima (Šupuković i dr. 2016). Osim njima manipulacija drvnim proizvodima, a posebice jednometarskim ogrjevnim drvom, obavlja se i ostalim teretnim automobilima bez hidraulične dizalice široke namjene ili s njima.

Kao i kod svih drugih vozila, osnovni je uvjet za sudjelovanje u prometu da je vozilo tehnički isprav- 
no, ${ }^{14}$ a nakon redovite i periodične provjere tehničke ispravnosti i registrirano, ${ }^{15}$ što policijski službenici provjeravaju uvidom u prometnu dozvolu i vizualnim pregledom vozila, a prema potrebi i upućivanjem vozila na izvanredni tehnički pregled..$^{16} \mathrm{O}$ pregledu teretnoga vozila na mjestu nadzora policijski službenik sastavlja zapisnik, a u slučaju odlaska na tehnički pregled sastavlja ga stanica za tehnički pregled, odnosno ovlašteni ispitivač. Ovisno o utvrđenom statusu poduzeća/obrtnika/vozača, ako postoje nedostaci, podnose se odgovarajući optužni prijedlozi, odnosno izdaju se prekršajni nalozi ili na mjestu prekršaja naplaćuju novčane kazne, za što su policijski službenici neposredni ovlaštenici jer se radi o Zakonu o sigurnosti prometa na cestama. Uz navedene uvjete tehničke ispravnosti i registracije ove vrste prijevoza i vozila, policijski službenici trebaju obratiti posebnu pozornost i načinu smještaja tereta i njegova obilježavanja na vozilima, što je uvjetovano člancima 154-156, Zakona o sigurnosti prometa na cestama. Pri tome treba istaknuti da je praksa prekršajnih sudova da pri nadzoru dopuštene mase isključivo prihvaćaju zapisnike ovlaštenih ispitivača, ${ }^{17}$ za razliku od prijašnjega razdoblja kada su se vaganja ili mjerenja obavljala uvidom $u$ otpremnicu ili vaganjem na vagama raznih fizičkih i pravnih osoba široke namjene.

Vozač teretnoga vozila, traktora i pridodanih priključnih vozila, kojima se prevozi drvni šumski proizvodi (kao i svi drugi), kod sebe, sukladno odredbama Zakona o sigurnosti prometa na cestama, treba imati odgovarajuću vrstu vozačke dozvole za vozilo kojim upravljaju te prometnu dozvolu za motorno i priključno vozilo.

Kada obavlja djelatnost javnoga prijevoza tereta, sukladno odredbama Zakona o prijevozu u cestovnom prometu (u daljnjem tekstu ZPCP/18), i kada upravlja vozilima C1, C1E, C ili CE najveće dopuštene mase veće od 3,5 tone i njime prevozi drvne šumske proizvode, vozač zaposlen u pravnim osobama i obrtima kod sebe $\mathrm{u}$ vozilu mora imati:

$\Rightarrow$ vozačku dozvolu ili kvalifikacijsku karticu vozača u koju je upisana oznaka Unije "95“ (članak 12. stavak 6. ZPCP/18)

\footnotetext{
14 ČL. 236. Zakona o sigurnosti prometa na cestama. NN 67/08, 48/10, 74/11, 80/13, 158/13, 92/14, 64/15, 108/17, 70/19, 42/20.

15 ČL. 238. Zakona o sigurnosti prometa na cestama.

16 Čl. 258. Zakona o sigurnosti prometa na cestama.

17 Pravilnik o nadzoru osovinskog pritiska, ukupno dozvoljene mase i dimenzija vozila, NN 76/97, 141/02, kojim je propisano da nadzor obavljaju stručno osposobljeni zaposlenici Hrvatske uprave za ceste odnosno zaposlenici županijskih uprava za ceste, ili carinske uprave na graničnim prijelazima u suradnji s djelatnicima Ministarstva unutarnjih poslova.
}

$\Rightarrow$ potvrdu da vozilo zadovoljava posebne uvjete koji se odnose na izgled, starost, uređaje i opremu vozila, za vozila kojima se obavlja djelatnost javnoga cestovnoga prijevoza i cestovnoga prijevoza za vlastite potrebe (članak 13. ZPCP/18)

$\Rightarrow$ izvod iz licencije za unutarnji prijevoz ili ovjerenu vjerodostojnu presliku licencije Zajednice za međunarodni prijevoz (članak 23. stavak 14. ZPCP/18)

$\Rightarrow$ ugovor o najmu ako je vozilo unajmljeno (članak 78. $\mathrm{ZPCP} / 18)$

$\Rightarrow$ teretni list (članak 79. ZPCP/18 i 37. ZŠ/18)

$\Rightarrow \mathrm{u}$ slučaju najma vozila, kada vozač nije najmoprimac, u vozilu se mora nalaziti ugovor o radu ili ovjerena preslika ugovora o radu u kojem su navedeni podaci o najmoprimcu i vozaču, datum sklapanja ugovora o radu, rok trajanja ugovora o radu ili posljednji obračunski platni listić ili obrazac prijave vozača na zdravstveno i mirovinsko osiguranje (članak 78. ZPCP/18)

$\Rightarrow$ izvod prijave prijevoza za vlastite potrebe. Vozila koja se koriste za prijevoz za vlastite potrebe moraju biti u vlasništvu prijevoznika koji obavlja prijevoz za vlastite potrebe, ili moraju biti uzeta $\mathrm{u}$ zakup od prijevoznika na temelju ugovora o zakupu ili leasingu, ili moraju biti na raspolaganju za korištenje temeljem druge osnove (podzakup i sl.) (članak 93. ZPCP/18).

U slučaju neposjedovanja propisanih dokumenata policijski službenici nakon provedenih izvida, odnosno kriminalističkoga istraživanja, nadležnoj inspekciji cestovnoga prometa podnose obavijest o počinjenom prekršaju s obzirom na to da policija nije neposredni ovlaštenik provođenja Zakona o prijevozu u cestovnom prometu, i to s prethodno opisanim postupkom što kvalitetnijega prikupljanja dokaza. Dvojbu, koja se pojavljuje ako vozač nema teretni list, što je kažnjivo po Zakonu o prijevozu u cestovnom prometu i po Zakonu o šumama, potrebno je razriješiti kriminalističkim istraživanjem, koje treba dati odgovore je li za drvne proizvode uopće izdan teretni list, a tada bi prekršaj ušao u zonu kažnjavanja po Zakonu o šumama, ili upućivao na sumnju u počinjenje kaznenoga djela krađe, ili je došlo do lakšega prekršaja (kategorizacija iz članka 110. ZPCP) vozača koji je teretni list zagubio, zaboravio ili slično, o čem se onda obavijest dostavlja inspekciji cestovnoga prometa. ${ }^{18}$

Vozila čija je najveća dopuštena masa s priključnim vozilom veća od 3,5 tone u Republici Hrvatskoj

\footnotetext{
18 Prekršajne odredbe Zakona o prijevozu u cestovnom prometu nalaze se u XVII. dijelu Zakona.
} 
moraju imati ugrađen tahograf, što je i obveza u pogledu vožnji i ostalih aktivnosti vozača i vozačkoga osoblja propisano Zakonom o radnom vremenu, obveznim odmorima mobilnih radnika i uređajima za bilježenje u cestovnom prijevozu. ${ }^{19}$ Ako vozač upravlja vozilom opremljenim analognim tahografom, on mora predočiti, uvijek kada to zatraži ovlašteni službenik koji obavlja kontrolu, tahografske listiće za tekući dan te listiće koje je koristio prethodnih 28 dana i karticu vozača, ako je posjeduje. Ako vozač upravlja vozilom opremljenim digitalnim tahografom, on mora predočiti, uvijek kada to zatraži ovlašteni službenik koji obavlja kontrolu, ispise izvršene tijekom tekućega dana i u prethodnih 28 dana u skladu s člankom 10. Zakona o radnom vremenu, obveznim odmorima mobilnih radnika i uređajima za bilježenje u cestovnom prijevozu, odnosno Uredbom (EU) br. 165/2014 Europskoga parlamenta i vijeća od 4. veljače $2014 .{ }^{20}$ Zakonom o radnom vremenu, obveznim odmorima mobilnih radnika i uređajima za bilježenje u cestovnom prijevozu propisano je da su uz inspektore cestovnoga prometa i policijski službenici ovlaštenici za provođenja zakona. ${ }^{21}$

Daljinski se transport drvnih proizvoda obavlja teretnim motornim vozilima, kamionima, a posebice ogrjevno drvo često se prevozi i traktorima s pridodanim poluprikolicama ili prikolicama opće namjene ili posebno prilagođenim za prijevoz drvnih proizvoda, tzv. metrice. Opći uvjeti za sudjelovanje u prometu, kao i kod drugih vozila i sudionika, jesu da su vozila tehnički ispravna, osigurana i registrirana te da vozač posjeduje odgovarajuću vozačku dozvolu. Kod traktora, kao i kod teretnih automobila kako je već navedeno, za tehničku ispravnost primjenjuje se članak 236, a za registraciju članak 238, dok se za vozačevo upravljanje vozilom primjenjuju članci 216. i 217. Zakona o sigurnosti prometa na cestama. Zakonom o obveznim osiguranjima $\mathrm{u}$ prometu $\mathrm{u}^{22}$ propisuje se da je vlasnik dužan prije uporabe prijevoznoga sredstva $u$ prometu sklopiti ugovor o osiguranju i obnavljati ga dok je prijevozno sredstvo u prometu.

\footnotetext{
19 Zakon o radnom vremenu, obveznim odmorima mobilnih radnika i uređajima za bilježenje u cestovnom prijevozu. NN 75/2013, 36/2015 i 46/2017.

20 http://eur-lex.europa.eu/legal-content/HR/TXT/HTML/?u$\mathrm{ri}=$ CELEX:32014R0165\&from=HR; pristupljeno 17. 4. 2017.

21 Propisana novčana kazna za vozača je od 1000,00 do 2000,00 kuna člankom 48. Zakon o radnom vremenu, obveznim odmorima mobilnih radnika i uređajima za bilježenje u cestovnom prijevozu. NN 75/2013, 36/2015 i 46/2017.

22 Čl. 4. i 65 . Zakona o obveznim osiguranjima u prometu. NN 151/05, 36/09, 75/09, 76/13, 152/14.
}

\section{Nadzor policijskih službenika u prometu i njihovo postupanje - Traffic control by police officers and their conduct}

Iako, kako je već navedeno, policijski službenici nisu neposredni ovlaštenici provođenja ZŠ/18, ipak obveze iz Zakona o policiji i obveze suradnje svih državnih tijela te činjenice da se gotovo ne može pri ovoj vrsti prijevoza izbjeći i nadzor tereta (uz nadzor zakona za koje su policijski službenici ovlašteni) nameću policijskim službenicima obvezu poznavanja osnovnih odrednica ZŠ/18 i njihovu primjenu u suradnji sa šumarskom inspekcijom, ili samostalno kada ona ne može izići na teren, te pokušati što više standardizirati postupanja.

Prilikom zaustavljanja bilo kojega prometnoga sredstva u prometu izvan šume i šumskoga zemljišta, koje prevozi drvne proizvode, uz već opisane opće uvjete za sudjelovanje u prometu, policijski službenik od vozača treba zatražiti teretni list (popratnicu) za drvo koji može biti izdan kao ispis iz računalne baze podataka. Teretni list mora sadržavati sve podatke koje sadrže i obrasci teretnoga lista za oblo drvo na obrascu TL-1, prostorno drvo i drvnu sječku na obrascu TL-2 i nedrvne šumske proizvode na obrascu TL-NŠP. ${ }^{23}$ Važno je istaknuti da sve vrste drvnih proizvoda i sa svih područja u prometu moraju imati teretni list (popratnicu), jer je uz izdavanje teretnoga lista za drvo posječeno u šumi Pravilnikom o doznaci stabala, obilježbi šumskih proizvoda, teretnom listu (popratnici) i šumskom redu i šumskoga zemljišta propisano da popratnicu treba imati i drvo posječeno izvan šume i šumskoga zemljišta.

Policijski službenik neposrednim opažanjem utvrđuje kod svih vrsta drvnih sortimenta, odnosno teretnoga lista (popratnica) i tereta sljedeće:

$\Rightarrow$ odgovara li datum na popratnici datumu nadzora (rok je važenja popratnice za drvne sortimente i ostale šumske proizvode 24 sata ${ }^{24}$

$\Rightarrow$ odgovara li vrijeme otpreme na otpremnici mjestu i vremenu te smjeru kretanja vozila (može se uspoređivati s vremenom na zapisnom listu tahografa vozila)

$\Rightarrow$ podudaraju li se upisano mjesto utovara i istovara sa zatečenim odnosno utvrđenim smjerom kretanja vozila

$\Rightarrow$ jesu li podaci o prijevozniku, registarskoj oznaci i vozaču upisani na popratnici identični zatečenom na mjestu nadzora

\footnotetext{
23 Vidi dio IV. čl. 23-24 Pravilnika o doznaci stabala, obilježbi šumskih proizvoda, teretnom listu (popratnici) i šumskom redu. NN 71/2019.

24 Čl. 23. Pravilnika iz prethodne točke.
} 
$\Rightarrow$ je li teretni list (popratnica) ovjeren žigom ili faksimilom režijskoga čekića licenciranoga izvođača koji je obavio obilježavanje drvnih sortimenata, odnosno je li otisak žiga na drvnom sortimentu u prijevoznom sredstvu i na popratnici isti

$\Rightarrow$ odgovara li vrsta drveta naznačena u popratnici (bukva, hrast, jela itd.) tovaru na vozilu te odgovara li okvirno količina u kubnim metrima zatečenomu. Iskustveni pokazatelji upućuju na to da teretni automobil za prijevoz trupaca okvirno može prevoziti oko $10 \mathrm{~m}^{3}$, a njegovo priključno vozilo do oko $12 \mathrm{~m}^{3}$, što ovisi o vrsti robe i njezinoj vlažnosti. Istodobno, poluprikolice pridodane traktorima okvirno mogu prevoziti od približno $3 \mathrm{~m}^{3}$ pa do $5 \mathrm{~m}^{3}$, a najveće i do $7 \mathrm{~m}^{3}$

$\Rightarrow$ je li drvni sortiment obilježen režijskim čekićem koji ima oblik istostraničnoga trokuta zaobljenih vrhova i dužine stranice od $35 \mathrm{~mm}$, i to na čelu sortimenta vidljivim otiskom

$\Rightarrow$ jesu li drvni sortimenti obloga tehničkoga drva (trupci, tanka oblovina i obla građa) srednjega promjera ispod $25 \mathrm{~cm}$ obilježeni na jednom čelu, a srednjega promjera $25 \mathrm{~cm}$ i većega na oba čela

$\Rightarrow$ je li višemetarsko prostorno drvo promjera $7 \mathrm{~cm}$ i većega obilježeno u složaju na $50 \%$ komada $\mathrm{s}$ jedne strane složaja

$\Rightarrow$ je li jednometarsko prostorno drvo promjera 7 cm i većega obilježeno u složaju na $50 \%$ cjepanica odnosno oblica $s$ jedne strane složaja ili 30 $\%$ sa svake strane složaja. Je li prostorno drvo dimenzija kraćih od 1 m obilježeno na jednom čelu, i to na $20 \%$ cjepanica odnosno oblica

$\Rightarrow$ jesu li drvni sortimenti obloga tehničkoga drva obilježeni identifikacijskom pločicom. ${ }^{25}$

Ako neki od pokazatelja naznačeni u popratnici odudaraju od zatečenoga, valja provesti kriminalističko istraživanje. Kriminalističko istraživanje je ukupnost onih policijskih ovlasti, mjera i radnji koje se prema ovom ili drugim zakonima poduzimaju kada postoji osnova sumnje da se priprema ili je počinjeno kazneno djelo za koje se progoni po službenoj dužnosti ili prekršaj, ili postoji sumnja da određena pojava ugrožava ili bi mogla ugroziti živote ljudi, njihova prava, slobodu, sigurnost, nepovredivost ili imovinu. Zatim radi otkrivanja kaznenoga djela za koje se progoni po službenoj dužnosti ili prekršaja, pronalaženja počinitelja, sprječavanja da se počinitelj sakrije ili pobjegne, da se otkriju ili osiguraju tragovi i predmeti koji mogu poslužiti pri utvrđivanju činje-

\footnotetext{
25 Vidi dio III. čl. 18-21 Pravilnika o doznaci stabala, obilježbi šumskih proizvoda, teretnom listu (popratnici) i šumskom redu. NN 71/2019.
}

nica i da se prikupe obavijesti koje mogu biti od koristi za postupak. ${ }^{26} \mathrm{U}$ ovom slučaju treba obuhvatiti vozača i vozačko osoblje, naznačenoga kupca, prijevoznika, te otpremnika i u pravilu predstavnika poduzeća koje je obavilo otpremu, kao i eventualno druge osobe koje raspolažu spoznajama o događaju.

Kriminalističkim istraživanjem utvrđenih odudaranja zatečenoga stanja pri nadzoru vozila i tereta te opisanom stanju u popratnici mogu se utvrditi:

$\Rightarrow$ prekršaji iz Zakona o šumama ${ }^{27}$ (članci 36-39), a ovlaštenik je za pokretanja prekršajnoga postupka šumarska inspekcija, te ako je u mogućnosti izići, svakako valja pozvati inspektora na mjesto događaja, odnosno ako nije u mogućnosti, izvijestiti ga telefonom o izvidima koji će biti poduzeti i o utvrđenom stanju zbog čega će mu policijski službenik podnijeti obavijest o prekršaju

$\Rightarrow$ prekršaji iz Zakona o trgovini $^{28}$ gdje se može sumnjati na obavljanje neregistrirane trgovačke djelatnosti, prodaje, preprodaje i dr., za koji su zakon ovlaštenici provođenja nadzora nadležni tržišni inspektori prema Zakonu o državnom inspektoratu, te ako je u mogućnosti izići na mjesto događaja, svakako treba pozvati inspektora, odnosno ako nije u mogućnosti, izvijestiti ga telefonom o izvidima koji će biti poduzeti i o utvrđenom stanju zbog čega će mu policijski službenik podnijeti obavijest o prekršaju

$\Rightarrow$ prekršaji iz Zakona o zabrani i sprječavanju obavljanja neregistrirane djelatnosti kada pravna osoba obavlja djelatnost koja nije upisana $u$ sudski registar ili drugi odgovarajući registar, ili nema zakonom propisane akte o ispunjavanju uvjeta za obavljanje registrirane djelatnosti, kada fizička osoba obavlja djelatnost koju nije registrirala kod nadležnoga tijela ili prijavila poreznim tijelima, ili nema zakonom propisane akte o ispunjavanju uvjeta za obavljanje registrirane djelatnosti i kad pravna ili fizička osoba obavlja djelatnost unatoč zabrani obavljanja djelatnosti. ${ }^{29}$ Ovlaštenici nadzora po ovom zakonu također su tržišni inspektori, kojima policija dostavlja obavijest, ako samostalno postupa i prikupi podatke o prekršajima iz ovoga zakona.

\footnotetext{
26 Zakon o policijskim poslovima i ovlastima. NN 76/2009, 92/2014, 70/19.

27 Vidi dio XI. Zakon o šumama. NN 68/18, 115/18, 98/19, 32/20, 145/20.

28 Čl. 4. i s njim u svezi čl. 71. Zakona o trgovini. NN 87/08, 96/08, 116/08, 76/09, 114/11, 68/13, 30/14.

29 Zakon o zabrani i sprječavanju obavljanja neregistrirane djelatnosti. NN 61/11, 66/19.
} 
$\Rightarrow$ kazneno djelo »krivotvorenja isprave « iz članka 278. Kaznenoga zakona RH-a koje čini onaj tko izradi lažnu ispravu ili preinači pravu s ciljem da se takva isprava uporabi kao prava, ili tko takvu ispravu nabavi radi uporabe ili je uporabi kao pravu. ${ }^{30}$ Koliko je isprava, toliko je mogućih krivotvorenja. Policijski službenici mogu posumnjati prilikom nadzora $\mathrm{u}$ pogledu vjerodostojnosti i odrednica toga članka ako su teretni listovi (popratnice) djelomično ispunjeni, ako nisu za dan prijevoza, ako otisak na teretnom listu nije jednak kao na drvetu, ako registarska pločica na vozilu i podaci na popratnici nisu isti, ako vrsta drveta upisana u popratnicu i na teretni list nije jednaka i dr. U tom slučaju obvezno treba provesti kriminalističko istraživanje.

$\Rightarrow$ kazneno djelo »zlouporaba položaja i ovlasti« iz članka 291. KZ/11 Republike Hrvatske koje čini ona službena ili odgovorna osoba koja iskoristi svoj položaj ili ovlast, prekorači granice svoje ovlasti ili ne obavi dužnost pa time sebi ili drugoj osobi pribavi protupravnu korist ili drugomu prouzroči štetu. Sumnju na ovo kazneno djelo može potaknuti također nepotpuna ili uopće nepostojeća dokumentacija za drvne proizvode $\mathrm{u}$ transportu uz izjavu vozača da je službena osoba organizacije odobrila transport. Češće se do podataka o ovim kaznenim djelima dolazi javnim pogovorom ili preko informatora.

$\Rightarrow$ kazneno djelo »pustošenje šuma« iz članka 209. KZ/11 Republike Hrvatske koje čini onaj tko protivno propisima siječe ili krči šumu ili na drugi način pustoši šumu, a time ne čini neko drugo kazneno djelo za koje je propisana teža kazna

$\Rightarrow$ kazneno djelo »krađa« iz članka 228. KZ/11 Republike Hrvatske koje čini onaj tko tuđu pokretnu stvar oduzme drugomu s ciljem da je protupravno prisvoji.

U slučaju postojanja osnove sumnje da su počinjena neka od prethodno navedenih kaznenih djela policija postupa po članku 207. Zakona o kaznenom postupku Republike Hrvatske, a nakon provedenih izvida nadležnomu državnomu odvjetniku podnosi kaznenu prijavu protiv počinitelja ili posebno izvješće. ${ }^{31}$

\footnotetext{
30 Čl. 278. Kaznenoga zakona RH. NN 125/11, 144/12, 56/15, 61/15, 101/17, 118/18, 126/19.

31 Čl. 207. Zakona o kaznenom postupku. NN 152/08, 76/09, 80/11, 121/11, 91/12, 143/12, 56/13, 145/13, 152/14, 70/17: (1) Ako postoje osnove sumnje da je počinjeno kazneno djelo za koje se kazneni postupak pokreće po službenoj dužnosti, policija ima pravo i dužnost poduzeti potrebne mjere:

1) da se pronađe počinitelj kaznenog djela, da se počinitelj ili sudionik ne sakrije ili ne pobjegne,
}

Kako bi osigurali dokaze u kaznenom ili prekršajnom postupku, policijski službenici trebaju poduzeti dokazne i druge radnje iz Zakona o kaznenom postupku, Prekršajnoga zakona te Zakona o policijskim poslovima i ovlastima kojima će biti osigurano uspješno vođenje postupka protiv počinitelja, a najčešće:

$\Rightarrow$ očevid (na vozilu, u šumi, mjestu utovara, istovara ili drugom mjestu ovisno o slučaju)

$\Rightarrow$ privremeno oduzimanje predmeta (drvnih proizvoda, teretnoga lista, tahografskoga zapisa, prema potrebi dokumentacije o prodaji, prijevozu ili čak alata) koji se predaju na čuvanje djelatnicima šumarije ili oštećenima

$\Rightarrow$ pregled ili pretragu.

Navedeni prekršaji i kaznena djela mogu se odnositi na slučaj kada vozač kod sebe ima popratnicu i kada se sumnja u zatečeno neposrednim opažanjem na vozilu i na unesene pokazatelje $u$ rubrike popratnice, ali i za slučaj kada vozač uopće nema popratnice.

Kada vozač pri prijevozu drvnih sortimenata nema popratnice, kriminalističko istraživanje $u$ pravilu kreće $u$ smjeru osnova sumnje $u$ počinjenje kaznenoga djela krađe ili pustošenja šuma koja su opisana u prethodnom dijelu teksta, a djelatnici prometne ili temeljne policije istraživanje trebaju prepustiti djelatnicima kriminalističke policije. U kriminalističkom istraživanju, izvidima i dokaznim radnjama odmah valja krenuti s obavijesnim razgovorom s vozačem i drugim zatečenim osobama, provjeri alibija, utvrđivanju točnoga činjeničnoga stanja u pogledu mjesta od kuda potječe drvni proizvod, odnosno tko je oštećen (Republika Hrvatska ili fizičke osobe) te oduzimanjem predmeta kaznenoga djela, u ovom slučaju drva. Očevid valja obaviti na prijevoznom sredstvu na kojem se nalazi drvni sortiment koji se fotografira, mjeri i opisuje zapisnikom o očevidu, a nakon toga na mjestu događaja u šumi ili mjestu gdje je drvo posječeno, koje pokaže počinitelj. Kako je prije navedeno, ako osumnjičenik tvrdi da je sječa obavljena zakonito, traga se za panjevima i oznakama doznačnoga čekića, koji se fotografiraju.

Tijekom očevida na mjestu sječe utvrđuje se točna lokacija štetnoga događaja i oštećenik, te se mjere i dokumentiraju zatečeni tragovi, a to su u ovom slučaju najčešće panjevi i vrhovi stabala koji se premjeravaju i fotografiraju, odnosno uspoređuju s drvnim

2) da se otkriju i osiguraju tragovi kaznenog djela i predmeti koji mogu poslužiti pri utvrđivanju činjenica te

3) da se prikupe sve obavijesti koje bi mogle biti od koristi za uspješno vođenje kaznenog postupka. 
sortimentima zatečenim na prijevoznom sredstvu. Za određivanje lokacije, a potom vlasnika i visine štete te oštećenoga policijski službenici tijekom izvida mogu i trebaju koristiti oštećene osobe, ovlaštene geodete, zaposlene pri Hrvatskim šumama ili samostalno, te djelatnike Hrvatskih šuma i šumarske inspekcije koji su ovlašteni za pojedine radnje iz svoje domene. Za početak izvida vezano uz lokaciju događaja i utvrđivanje oštećenoga moguće je koristiti otvorene dostupne aplikacije: geoportal ${ }^{32}$, e-izvadak $^{33}$ i preglednik ARKOD.

\section{Zaključak - Conclusion}

Iako je ponekad zanemarivana opasnost od kaznenih djela i prekršaja u vezi s drvnim i nedrvnim šumskim proizvodima, ipak je riječ o ozbiljnoj prijetnji zaštiti biološke osnove i raznovrsnosti šuma te o gospodarenju na realnim osnovama, a također često o zlouporabi dokumentacije i izbjegavanju plaćanja svih propisanih davanja, čime se društvu u cijelosti nanosi značajna materijalna šteta, što jasno upućuje na potrebu pripremanja i osposobljavanja policijskih službenika u suradnji sa šumarskom inspekcijom za djelovanje u takvim situacijama.

Ako osposobljeni službenici poduzmu kvalitetne operativno taktičke radnje i dosljednije kriminalističko istraživanje, broj tih kažnjivih djela trebao bi biti manji, a time i štetan utjecaj na okoliš i državni proračun. U radu se uočava da se pri ovim postupanjima isprepleće čitava lepeza zakona pa je nužno uključivanje više službi u policiji i ostalih inspekcijskih tijela. Jasno je da je policija zbog same činjenice da, primjerice, u Požeško-slavonskoj županiji postoji samo jedan šumarski inspektor, nositelj ključne uloge u ovakvim događajima, što stavlja na test policijskoga službenika koji svakodnevno mora širiti spektar znanja kako bi se mogao nositi s novim oblicima ugrožavanja.

\section{Literatura-References}

Gospočić, S., 2018: Primjena odredbi Prekršajnoga zakona u prekršajnim postupcima pred tijelima državne uprave, Priručnik za polaznike. Pravosudna akademija, Zagreb.

Kazneni zakon. NN 125/11, 144/12, 56/15, 61/15, 101/17, 118/18, 126/19.

Peulić, V., G. Matijević, 2018: Najčešći utvrđeni prekršaji iz zakona o radnom vremenu, obveznim odmorima mo-

32 https://geoportal.dgu.hr; pristupljeno 17. 4. 2021.

33 https://oss.uredjenazemlja.hr/public/lrextracts.jsp?actio$\mathrm{n}=$ publicLdbExtract; pristupljeno 17. 4. 2021. bilnih radnika i uređajima za bilježenje $\mathrm{u}$ cestovnom prijevozu Europske unije na primjeru Republike Hrvatske. EDASOL, Banja Luka, BiH.

Peulić, V., N. Palić, G. Matijević, 2017: Pojedini zakonski modeli iz Prekršajnog zakona RH-e, sukladno kojima se počiniteljima ne izriče novčana kazna ili druga prekršajno pravna sankcija. CEPS, Kiseljak, BIH.

Podhraški, F., S. Tršinski, 2009: Postupanje policije po odredbama Prekršajnog zakona. Policijska sigurnost, 18(2): 247-261.

Pravilnik o doznaci stabala, obilježbi šumskih proizvoda, teretnom listu (popratnici) i šumskom redu. NN 71/19.

Pravilnik o nadzoru osovinskog pritiska, ukupno dozvoljene mase i dimenzija vozila. NN 76/97, 141/02.

Prekršajni zakon. NN 107/07, 39/13, 157/13, 110/15, 70/17, $118 / 18$.

Šupuković, V., S. Jakupović, V. Peulić, 2016: Menadžment cestovnog prijevoza. Grafid d.o.o., Zagreb.

Zakon o Državnom inspektoratu. NN 115/18.

Zakon o kaznenom postupku. NN 152/08, 76/09, 80/11, 121/11, 91/12, 143/12, 56/13, 145/13, 152/14, 70/17.

Zakon o obveznim osiguranjima u prometu. NN 151/05, 36/09, 75/09, 76/13, 152/14.

Zakon o policiji. NN 34/11, 130/12, 89/14, 151/14, 33/15,121/16, 66/19.

Zakon o policijskim poslovima i ovlastima. NN 76/09, 92/14, 70/19.

Zakon o prijevozu u cestovnom prometu. NN 41/18, 98/19, 30/21.

Zakon o radnom vremenu, obveznim odmorima mobilnih radnika i uređajima za bilježenje u cestovnom prijevozu. NN 75/13, 36/15 i 46/17.

Zakon o sigurnosti prometa na cestama. NN 67/08, 48/10, 74/11, 80/13, 158/13, 92/14, 64/15, 108/17, 70/19, 42/20.

Zakon o šumama. NN 68/18, 115/18, 98/19, 32/20, 145/20.

Zakon o trgovini. NN 87/08, 96/08, 116/08, 76/09, 114/11, 68/13, 30/14, 32/19, 98/19, 32/20.

Zakon o zabrani i sprječavanju obavljanja neregistrirane djelatnosti. NN 61/11, 66/19.

Zečić, Ž., D. Vusić, 2020: Katalog drvnih šumskih proizvoda. Šumarski fakultet Sveučilišta u Zagrebu - Hrvatske šume d.o.o. Zagreb, Og-grafika d.o.o., Zagreb.

https://geoportal.dgu.hr

https://oss.uredjenazemlja.hr/public/lrextracts.jsp?actio$\mathrm{n}=$ publicLdbExtract

http://eur-lex.europa.eu/legal-content/HR/TXT/ HTML/?uri=CELEX:32014R0165\&from $=$ HR 


\section{Abstract}

\section{Some Determinants of Police Conduct in Cases of Violation of Forest Law and other Illegal Forest Related Activities}

Forests and forest lands are specific natural resources of the Republic of Croatia. Private and public forest owners have the primary task of providing sustainable forest management, with state forests being managed by Hrvatske šume Ltd. and other institutions. In accordance with the Law on State Inspectorate, inspection and supervision in forestry are the responsibility of the forestry inspection, and within the Croatian Forests, audit and supervision departments have been established. In addition, police officers play an indispensable role in the prevention and detection of forest-related offenses and criminal activities, thus contributing to the interests of the Republic of Croatia in terms of forest protection. This paper contains proposed instructions for their conduct, but may also be useful to other inspections and services to identify illegal activities during the control of felling, transport and trade of forest products (wood and non-wood), when people are found in violation of law in this area and in the case of other criminal offenses and misdemeanors. Furthermore, instructions are given on how to properly establish the facts through criminal investigation and how to submit appropriate letters with attachments, i.e. evidence to the competent inspection, misdemeanor courts or the State Attorney's Office. At the same time, several cases of illicit acts described in this paper may have the characteristics of the criminal offenses of theft, forgery of documents, verification of false content, and abuse of position and authority. The paper also includes the procedure of criminal investigation, survey and submission of an appropriate report or criminal report to the competent State Attorney's Office, which is responsible for prosecuting of perpetrators of criminal offenses, and is legitimate in accordance with its powers.

Keywords: legal regulations, forest products, misdemeanor, criminal offense, police inspection

Primljeno (Received): 26. 8. 2021.

Prihvaćeno (Accepted): 15. 10. 2021.
Adrese autorâ - Authors' addresses:

Dr. sc. Goran Matijević

e-pošta: gmatijevic1974@gmail.com

Ministarstvo unutarnjih poslova

PU požeško-slavonska

Ul. Josipa Runjanina 1

34000 Požega

HRVATSKA

Doc. dr. sc. Malči Grivec

e-pošta: malci.grivec@uni-nm.si

Univerzitet u Novom Mestu

Fakultet za ekonomiju i informatiku

Na Loko 2

8000 Novo mesto

SLOVENIJA

Prof. dr. sc. Željko Zečić *

e-pošta: zzecic@sumfak.hr

Sveučilište u Zagrebu

Fakultet šumarstva i drvne tehnologije

Svetošimunska 23

10000 Zagreb

HRVATSKA

${ }^{*}$ Glavni autor - Corresponding author 